\title{
Proses Linierisasi Model Kinerja Lembaga Komisi Pemberantasan Korupsi Periode 2017 - 2019
}

\author{
The Process of Linearizing The Performance Corruption Model \\ 2017 - 2019 Period
}

\author{
Cynthia Alvionita Ferima \\ Universitas Pesantren Tinggi Darul 'Ulum Jombang \\ Alamat email: cynthia.alvionita@mipa.unipdu,ac.id
}

\begin{abstract}
Abstrak - Model prey - predator dikembangkan pada kinerja lembaga Komisi Pemberantasan Korupsi dalam menangani kasus korupsi. Banyaknya koruptor dapat dikontrol dengan pemberian sanksi berupa hukuman kurungan atau penjara. Fungsi tujuan penelitian ini adalah mengetahui proses linierisasi pada model kinerja lembaga komisi pemberantasan korupsi sebagai bahan pembelajaran menganalisis kestabilan, keterkontrolan dan keteramatan. Adapun metode dalam penelitian ini adalah langkah awal proses linierisasi dengan menggunakan ekspansi deret Taylor dan kemudian diperoleh matriks Jacobi untuk menganalisis kestabilan, keterkontrolan, dan keteramatan pada model kinerja lembaga komisi pemberantasan korupsi. Adapun untuk hasil penelitian ini adalah analisis kestabilan yang diperoleh jika $\gamma_{2}$ memenuhi kriteria kestabilan, maka $\gamma_{2}<0$ stabil asimtotik dengan syarat $c>d, X_{1}>X_{2}$ dan untuk $\gamma_{1}$ agar diperoleh stabil maka $\gamma_{1}<0$. Analisis keterkontrolan yang diperoleh $M_{c}$ mempunyai rank sama dengan 2 berakibat sistem terkontrol. Analisis keteramatan yang diperoleh matriks $M_{o}$ mempunyai rank sama dengan 2 sehingga sistem teramati.
\end{abstract}

Kata kunci: korupsi, koruptor, model prey predator, proses linierisasi, analisis kestabilan, analisis keterkontrolan, analisis keteramatan

\begin{abstract}
The prey - predator model was developed on the performance of the Corruption Eradication Commission in handling corruption cases. The number of corruptors can be controlled by imposing sanctions in the form of imprisonment or imprisonment. The purpose of this study is to determine the linearization process in the performance model of the corruption eradication commission as a learning material to analyze stability, controllability and observation. The method in this research is the initial step of the linearization process using Taylor series expansion and then the Jacobi matrix is obtained to analyze the stability, controllability, and observations of the performance model of the corruption eradication commission agency. As for the results of this study is the stability analysis obtained if $\gamma_{2} 2$ meets the stability criteria, then $\gamma_{-} 2<0$ is asymptotically stable with the conditions $c>d, X_{-} 1>X_{-} 2$ and for $\gamma_{-} 1$ to be obtained stable then $\gamma_{-} 1<0$. The controllability analysis obtained by $M_{-} c$ has a rank equal to 2 resulting in a controlled system. The observation analysis obtained by the M_o matrix has a rank equal to 2 so that the system is observed.
\end{abstract}

Keywords: corruption, corruptor, predatory prey model, process of linearization, analysis of stability, analysis of controllability, analysis of observability

(C) 2020 Jurnal Jejaring Matematika dan Sains. This work is licensed under a $\underline{C C B Y-N C 4.0}$

\section{PENDAHULUAN}

Korupsi merupakan sebuah fenomena lama yang membawa dampak besar bagi pertumbuhan sektor ekonomi dan kehidupan bermasyarakat. Beberapa penelitian terdahulu yang membahas model masalah korupsi, yaitu model Schelling, model Lui, model Blackburn et al, model Mishra, model Caulkins dkk, dan model Richard dkk. Model matematika korupsi yang digunakan dalam penelitian ini adalah model prey predator dengan koruptor diasumsikan sebagai prey dan pegawai Komisi Pemberantasan Korupsi diasumsikan predator. Berikut model prey - predator yang dikenalkan Lotka Volterra.

$$
\begin{aligned}
& \frac{d X_{1}}{d t}=\dot{X}_{1}=a X_{1}-b X_{1} X_{2} \\
& \frac{d X_{2}}{d t}=\dot{X}_{2}=-c X_{2}+b X_{1} X_{2}
\end{aligned}
$$

Variabel $\dot{X}_{1}$ merupakan laju pertumbuhan mangsa dipengaruhi oleh $a$ koefisien pertumbuhan mangsa dengan jumlah mangsa $X_{1}$ mengakibatkan bertambah laju pertumbuhan mangsa dan $b$ koefisien interaksi antara mangsa dan pemangsa dengan jumlah interaksi mangsa dengan pemangsa mengakibatkan berkurangnya laju pertumbuhan mangsa. Jumlah populasi mangsa $X_{1}$ berkurang dengan semakin besarnya interaksi antara mangsa dan pemangsa $X_{1} X_{2}$. Sedangkan $\dot{X}_{2}$ laju pertumbuhan pemangsa dipengaruhi oleh koefisien 
pertumbuhan pemangsa $c$ dengan pemangsa akan semakin berkurang tanpa adanya interaksi antara mangsa dan pemangsa. Laju pertumbuhan pemangsa $\dot{X}_{2}$ akan bertambah jika terdapat interaksi antara mangsa dan pemangsa dengan koefisien interaksi mangsa dan pemangsa $b$.

Penelitian ini bertujuan mengetahui proses linierisasi pada model kinerja lembaga komisi pemberantasan korupsi sebagai bahan pembelajaran menganalisis kestabilan, keterkontrolan dan keteramatan.

\section{METODE PENELITIAN}

Adapun metode dalam penelitian ini adalah langkah awal proses linierisasi dengan menggunakan ekspansi deret Taylor dan kemudian diperoleh matriks Jacobi untuk menganalisis kestabilan, keterkontrolan, dan keteramatan pada model kinerja lembaga komisi pemberantasan korupsi periode 2017 - 2019.

\section{A. Pustaka}

Pustaka [1] definisi korupsi Menurut Undang-Undang No.31 Tahun 1999 tentang Pemberantasan Tindak Pidana Korupsi, yang termasuk dalam tindak pidana korupsi adalah setiap orang yang dikategorikan melawan hukum, melakukan perbuatan memperkaya diri sendiri, menguntungkan diri sendiri atau orang lain atau suatu korporasi, menyalahgunakan kewenangan maupun kesempatan atau sarana yang ada padanya karena jabatan atau kedudukan yang dapat merugikan keuangan negara atau perekonomian negara.

Pustaka [2] Model matematika korupsi yang digunakan adalah model prey - predator dengan koruptor diasumsikan prey dan pegawai KPK diasumsikan predator. Adapun beberapa alasan mengasumsikan model korupsi dengan menggunakan model prey predator, yaitu terdapatnya kesamaan pada sistem jika prey mengalami kepunahan atau mati disebabkan oleh kehabisan makanan, maka predator akan mengalami kepunahan atau mati pula disebabkan prey mengalami kepunahan. Sedangkan pada model kinerja lembaga KPK dalam menangani koruptor, yaitu jika koruptor (prey) berkurang atau telah tertangkap disebabkan adanya tindakan dari KPK, maka pegawai KPK (predator) juga berkurang atau habis disebabkan oleh koruptor (prey) berkurang. Selain itu, model prey predator dikenal dengan adanya interaksi antara prey dan predator adalah interaksi makan dan dimakan, sedangkan dalam model korupsi asumsinya adalah interaksi antara pegawai KPK (predator) dan instansi kepolisian serta kejaksaan untuk melakukan penindakan terhadap koruptor (prey). Dalam hal ini, penindakan yang dilakukan berupa

$$
\left.\begin{array}{c}
\dot{x}=f(x, u), \quad x \in \mathbb{R}^{n}, \quad u \in \mathbb{R}^{m} \\
\dot{y}=g(x, u), \quad y \in \mathbb{R}^{p} .
\end{array}\right\}
$$

penyelidikan, penyidikan, penuntutan, inkracht, dan eksekusi. Persamaan (-1) dikembangkan pada kontrol optimal kinerja lembaga KPK dalam menangani kasus korupsi dengan pemberian sanksi hukuman terhadap koruptor sehingga persamaan menjadi:

$$
\begin{aligned}
& \frac{d X_{1}}{d t}=\dot{X}_{1}(t)=a X_{1}-b X_{1} X_{2}-e U \\
& \frac{d X_{2}}{d t}=\dot{X}_{2}(t)=b X_{1} X_{2}+c X_{2}-d X_{2}
\end{aligned}
$$

dengan penjelasan berikut.

$\dot{X}_{1}(t) \quad$ Laju pertumbuhan koruptor pada waktu $t$

$\dot{X}_{2}(t) \quad$ Laju pertumbuhan pegawai KPK pada waktu

$X_{1}(t) \quad$ Jumlah koruptor pada waktu $t$

$X_{2}(t) \quad$ Jumlah pegawai KPK pada waktu $t$

$a \quad$ Rate pertumbuhan koruptor

$b \quad$ Rate interaksi pegawai KPK dengan instansi kepolisian dan kejaksaan dalam penindakan koruptor

c Rate pertumbuhan pegawai KPK

$d \quad$ Rate pemberhentian pegawai KPK

$e \quad$ Rate eksekusi koruptor

$U(t) \quad$ Variabel kontrol sanksi hukuman kurungan atau penjara terhadap koruptor pada waktu $t$

Dalam hal ini, rate pertumbuhan koruptor menyatakan tingkat pertumbuhan koruptor berdasarkan jabatan selama 2 tahun dari tahun 2017 hingga 2019 (dalam prosentase). Penentuan rate pertumbuhan koruptor dengan menghitung jumlahan prosentase selisih per tahun dibagi dengan waktu selama 2 tahun. Kemudian, rate interaksi pegawai KPK dengan instansi kepolisian dan kejaksaan dalam penindakan terhadap koruptor menyatakan tingkat interaksi pegawai KPK dengan instansi kepolisian dan kejaksaan dalam penindakan terhadap koruptor selama 2 tahun dari tahun 2017 hingga 2019 (dalam prosentase). Penentuan rate interaksi pegawai KPK dengan instansi kepolisian dan kejaksaan dalam penindakan terhadap koruptor dengan menghitung jumlahan prosentase selisih per tahun dibagi dengan waktu selama 2 tahun. Selanjutnya, rate pertumbuhan pegawai KPK menyatakan tingkat pertumbuhan pegawai KPK berdasarkan unit kerja selama 2 tahun dari tahun 2017 hingga 2019 (dalam prosentase). Penentuan rate pertumbuhan pegawai KPK dengan menghitung jumlahan prosentase selisih per tahun dibagi dengan waktu selama 2 tahun. Lalu, rate pemberhentian pegawai KPK menyatakan tingkat pemberhentian pegawai KPK selama 2 tahun dari tahun 2017 hingga 2019 (dalam prosentase). Penentuan rate pertumbuhan pemberhentian pegawai KPK dengan menghitung jumlahan prosentase selisih per tahun dibagi dengan waktu selama 2 tahun. Dan rate eksekusi koruptor menyatakan tingkat eksekusi yang diberikan kepada koruptor selama 2 tahun dari tahun 2017 hingga 2019 (dalam prosentase). Penentuan rate eksekusi koruptor dengan menghitung jumlahan prosentase selisih per tahun dibagi dengan waktu selama 2 tahun.

Pustaka [3] Berikut ini diturunkan konsep pelinearan secara lebih tepat. Tinjau suatu persamaan differensial non-linier diberikan berikut. (Subiono, 2013)

Diberikan suatu penyelesaian $\tilde{x}(),. \tilde{y}($.$) dan bila diberikan$ keadaan awal $\tilde{x}(0)=\tilde{x}_{0}$ dan masukan $\tilde{u}($.$) . Tinjau$ penyelesaian yang lain $\tilde{x}()+.z(),. \tilde{y}()+.w($.$) yang$ merupakan hasil dari $\tilde{x}(0)+z_{0}$ dan $\tilde{u}()+.v($.$) . Dalam$ beberapa makna $z_{0}$ dan $v($.) cukup kecil sedemikian 
hingga diharapkan $z($.$) dan w($.$) juga kecil, dalam hal ini$ diperoleh

$$
\begin{aligned}
& \frac{d}{d t} \tilde{x}(t)=f(\tilde{x}, \tilde{u}), \tilde{x}(0)=\tilde{x}_{0} \\
& \begin{aligned}
\frac{d}{d t}(\tilde{x}(t)+z(t)) & =f(\tilde{x}+z, \tilde{u}+v),(\tilde{x}+z)(0) \\
& =\tilde{x}_{0}+z_{0} .
\end{aligned}
\end{aligned}
$$

Namakan $\tilde{x}+z=\underline{x}$ dan $\tilde{u}+v=u$. Jadi, $f(\tilde{x}+z, \tilde{u}+$ $v)=f(\underline{x}, \underline{u})$, selanjutnya digunakan deret Taylor untuk $f(\underline{x}, \underline{u})$ disekitar $\underline{x}=\tilde{x}$ dan $\underline{u}=\tilde{u}$, didapat

$$
\begin{aligned}
f(\underline{x}, \underline{u})=f(\tilde{x}, \tilde{u}) & +\frac{\partial f}{\partial \underline{x}} z+\frac{\bar{\partial} f}{\partial \underline{u}} v \\
& + \text { suku tingkat dua keatas. }
\end{aligned}
$$

Tetapi, $\quad \frac{d}{d t}(\tilde{x}(t)+z(t))=f(\underline{x}, \underline{u}) \quad$ dan $\quad \frac{d}{d t}(\tilde{x}(t)+$ $z(t))=\frac{d}{d t} \tilde{x}+\frac{d}{d t} z(t)$.

Jadi, $\frac{d}{d t} \tilde{x}+\frac{d}{d t} z(t)=f(\tilde{x}, \tilde{u})+\frac{\partial f}{\partial x} z+\frac{\partial f}{\partial u} v+$

suku tingkat dua keatas.

Dengan kenyataan $z_{0}$ dan $v($.$) cukup kecil, maka suku -$ suku tingkat dua ke atas dapat diabaikan, sehingga diperoleh

$$
\frac{d}{d t} z(t)=\frac{\partial f}{\partial \underline{x}} z+\frac{\partial f}{\partial \underline{u}} v, z(0)=z_{0}
$$

Atau dalam bentuk matriks

$$
\begin{gathered}
\left(\begin{array}{c}
\frac{d z_{1}}{d t} \\
\frac{d z_{2}}{d t} \\
\vdots \\
\frac{d z_{n}}{d t}
\end{array}\right)=\left(\begin{array}{ccc}
\frac{\partial f_{1}}{\partial \underline{x}_{1}} & \ldots & \frac{\partial f_{1}}{\partial \underline{x}_{n}} \\
\frac{\partial f_{2}}{\partial \underline{x}_{1}} & \ldots & \frac{\partial f_{2}}{\partial \underline{x}_{n}} \\
\vdots & \ldots & \vdots \\
\frac{\partial f_{n}}{\partial \underline{x}_{1}} & \ldots & \frac{\partial f_{n}}{\partial \underline{x}_{n}}
\end{array}\right)\left(\begin{array}{c}
z_{1} \\
z_{2} \\
\vdots \\
\vdots \\
\vdots \\
z_{n}
\end{array}\right) \\
+\left(\begin{array}{cccc}
\frac{\partial f_{1}}{\partial \underline{u}_{1}} & \ldots & \frac{\partial f_{1}}{\partial \underline{u}_{m}} \\
\frac{\partial f_{2}}{\partial \underline{u}_{1}} & \ldots & \frac{\partial f_{2}}{\partial \underline{u}_{m}} \\
\vdots & \ldots & \vdots \\
\frac{\partial f_{n}}{\partial \underline{u}_{1}} & \ldots & \frac{\partial f_{n}}{\partial \underline{u}_{m}}
\end{array}\right)\left(\begin{array}{c}
v_{1} \\
v_{2} \\
\vdots \\
\vdots \\
\vdots \\
v_{m}
\end{array}\right)
\end{gathered}
$$

Persamaan $\quad \frac{d}{d t} z(t)=\frac{\partial f}{\partial \underline{x}} z+\frac{\partial f}{\partial \underline{u}} v, z(0)=z_{0} \quad$ adalah persamaan differensial keadaan hasil pelinearan disekitar titik $(\tilde{x}, \tilde{u})$. Dengan cara yang sama pelinearan untuk keluaran disekitar titik $(\tilde{x}, \tilde{u})$ adalah :

$$
w(t)=\frac{\partial g}{\partial \underline{x}} z(t)+\frac{\partial g}{\partial \underline{u}} v(t)
$$

Yang dapat ditulis dalam bentuk matriks

$$
\begin{aligned}
\left(\begin{array}{c}
w_{1} \\
w_{2} \\
\vdots \\
\vdots \\
\vdots \\
w_{p}
\end{array}\right)=\left(\begin{array}{ccc}
\frac{\partial g_{1}}{\partial \underline{x}_{1}} & \cdots & \frac{\partial g_{1}}{\partial \underline{x}_{n}} \\
\frac{\partial g_{2}}{\partial \underline{x}_{1}} & \ldots & \frac{\partial g_{2}}{\partial \underline{x}_{n}} \\
\vdots & \ldots & \vdots \\
\frac{\partial g_{p}}{\partial \underline{x}_{1}} & \cdots & \frac{\partial g_{p}}{\partial \underline{x}_{n}}
\end{array}\right)\left(\begin{array}{c}
z_{1} \\
z_{2} \\
\vdots \\
\vdots \\
\vdots \\
z_{n}
\end{array}\right) \\
+\left(\begin{array}{cccc}
\frac{\partial g_{1}}{\partial \underline{u}_{1}} & \ldots & \frac{\partial g_{1}}{\partial \underline{u}_{m}} \\
\frac{\partial g_{2}}{\partial \underline{u}_{1}} & \ldots & \frac{\partial g_{2}}{\partial \underline{u}_{m}} \\
\vdots & \ldots & \vdots \\
\frac{\partial g_{p}}{\partial \underline{u}_{1}} & \ldots & \frac{\partial g_{p}}{\partial \underline{u}_{m}}
\end{array}\right)\left(\begin{array}{c}
v_{1} \\
v_{2} \\
\vdots \\
\vdots \\
\vdots \\
v_{m}
\end{array}\right)
\end{aligned}
$$

Jika variabel $z, v$, dan $w$ masing - masing diganti dengan $x, u$ dan $y$, tetapi dalam hal ini tentunya berbeda dengan $x, u$, dan $y$ yang sebelumnya (asli), sehingga didapat:

$$
\begin{aligned}
& \dot{x}(t)=A(t) x(t)+B(t) u(t) \\
& \dot{y}(t)=C(t) x(t)+D(t) u(t),
\end{aligned}
$$

dengan

$$
\begin{aligned}
& A(t)=\left(\begin{array}{ccc}
\frac{\partial f_{1}}{\partial \underline{x}_{1}} & \cdots & \frac{\partial f_{1}}{\partial \underline{x}_{n}} \\
\frac{\partial f_{2}}{\partial \underline{x}_{1}} & \cdots & \frac{\partial f_{2}}{\partial \underline{x}_{n}} \\
\vdots & \cdots & \vdots \\
\frac{\partial f_{n}}{\partial \underline{x}_{1}} & \cdots & \frac{\partial f_{n}}{\partial \underline{x}_{n}}
\end{array}\right)_{\mid \underline{x}=\tilde{x}, \underline{u}=\widetilde{u}} \\
& B(t)=\left(\begin{array}{ccc}
\frac{\partial f_{1}}{\partial \underline{u}_{1}} & \cdots & \frac{\partial f_{1}}{\partial \underline{u}_{m}} \\
\frac{\partial f_{2}}{\partial \underline{u}_{1}} & \cdots & \frac{\partial f_{2}}{\partial \underline{u}_{m}} \\
\vdots & \cdots & \vdots \\
\frac{\partial f_{n}}{\partial \underline{u}_{1}} & \cdots & \frac{\partial f_{n}}{\partial \underline{u}_{m}}
\end{array}\right)_{\mid \underline{x}=\tilde{x}, \underline{u}=\widetilde{u}} \\
& C(t)=\left(\begin{array}{ccc}
\frac{\partial g_{1}}{\partial \underline{x}_{1}} & \cdots & \frac{\partial g_{1}}{\partial \underline{x}_{n}} \\
\frac{\partial g_{2}}{\partial \underline{x}_{1}} & \cdots & \frac{\partial g_{2}}{\partial \underline{x}_{n}} \\
\vdots & \cdots & \vdots \\
\frac{\partial g_{p}}{\partial \underline{x}_{1}} & \cdots & \frac{\partial g_{p}}{\partial \underline{x}_{n}}
\end{array}\right)_{\mid \underline{x}=\tilde{x}, \underline{u}=\tilde{u}} \\
& D(t)=\left(\begin{array}{ccc}
\frac{\partial g_{1}}{\partial \underline{u}_{1}} & \cdots & \frac{\partial g_{1}}{\partial \underline{u}_{m}} \\
\frac{\partial g_{2}}{\partial \underline{u}_{1}} & \cdots & \frac{\partial g_{2}}{\partial \underline{u}_{m}} \\
\vdots & \cdots & \vdots \\
\frac{\partial g_{p}}{\partial \underline{u}_{1}} & \cdots & \frac{\partial \underline{g}_{p}}{\partial \underline{u}_{m}}
\end{array}\right)_{\mid \underline{x}=\tilde{x}, \underline{u}=\tilde{u}}
\end{aligned}
$$

Hasil pelinearan sistem non linier adalah :

$$
\begin{aligned}
& \dot{x}(t)=A(t) x(t)+B(t) u(t) \\
& \dot{y}(t)=C(t) x(t)+D(t) u(t)
\end{aligned}
$$

Yaitu sistem linier tetapi umumnya varian - waktu.

Pustaka [4] Diberikan persamaan differensial tingkat satu $\dot{x}(t)=f(x(t))$ dengan $x \in \mathbb{R}^{n}$, penyelesaian dengan 
keadaan awal $x(0)=x_{0}$ dinotasikan oleh $x\left(t, x_{0}\right)$.(Subiono, 2013)

a. Vektor $\bar{x}$ yang memenuhi $f(\bar{x})=0$ disebut suatu titik setimbang.

b. Suatu titik setimbang $\bar{x}$ dikatakan stabil jika untuk setiap $\epsilon>0$ ada $\delta>0$ dan $t_{\delta}$ sedemikian hingga bila $\left\|x t_{\delta}-\bar{x}\right\|<\delta$ maka $\| x\left(t, x t_{\delta}\right)-$ $\bar{x} \|<\epsilon$ untuk semua $t>t_{\delta}$.

c. Suatu titik setimbang $\bar{x}$ dikatakan stabil asimtotik jika stabil dan ada $\delta_{1}>0$ sedemikian hingga $\lim _{t \rightarrow \infty}\left\|x t_{\delta}-\bar{x}\right\|=0$ jika $\left\|x t_{\delta}-\bar{x}\right\|<\delta_{1}$.

d. Suatu titik setimbang dikatakan tak stabil jika tak stabil.

Dalam definisi tersebut tanda $\|$.$\| berarti norm,$ biasanya digunakan norm Euclidean. Secara intuisi stabil berarti penyelesaian sangat dekat ke titik setimbang didalam suatu sekitar. Sedangkan stabil asimtotik berarti penyelesaian konvergen ke titik setimbang (asalkan titik awal adalah cukup dekat ke titik setimbang). Tak stabil artinya selalu ada penyelesaian yang dimulai dari manapun dekatnya dengan titik setimbang tapi akhirnya menjauh dari titik setimbang.

Untuk suatu persamaan differensial linear $\dot{x}=A x$ dengan $A$ berukuran $n \times n$, sebagai titik setimbang diambil titik asal $\bar{x}=0$ meskipun mungkin ada yang lainnya asalkan determinan matriks $A$ sama dengan nol. Untuk selanjutnya, dikatakan bahwa persamaan differensial $\dot{x}=$ $A x$ atau bahkan matriks $A$ itu sendiri adalah stabil asimtotik, stabil, atau tak stabil jika titik asal $\bar{x}=0$ sebagai titik setimbang adalah stabil asimtotik, stabil, atau tak stabil.

Diberikan sistem persamaan differensial tak linear sebagai berikut. (Boyce dan DiPrima, 2009)

$\frac{d X_{1}}{d t}=f\left(X_{1}, X_{2}\right)$

$\frac{d X_{2}}{d t}=g\left(X_{1}, X_{2}\right)$

Sebuah titik $\left(X_{1}^{*}, X_{2}^{*}\right)$ merupakan titik kesetimbangan dari persamaan di atas jika memenuhi $f\left(X_{1}, X_{2}\right)=$ $g\left(X_{1}, X_{2}\right)=0$. Jika turunan suatu konstanta sama dengan nol, maka fungsi konstan dari $X_{1}(t)=X_{1}^{*}$ dan $X_{2}(t)=X_{2}^{*}$ adalah penyelesaian kesetimbangan dari persamaan di atas untuk semua $t$.

Pustaka [5] Misalkan akar - akar persamaan karakteristik system persamaan (-3) adalah $\gamma_{1}$ dan $\gamma_{2}$ maka $\gamma_{1}$ dan $\gamma_{2}$ disebut nilai eigen. Nilai eigen tersebut digunakan untuk menentukan jenis kestabilan titik kesetimbangan system persamaan $(-3)$. Untuk memperoleh nilai eigen digunakan rumus $\operatorname{det}(Z-\gamma I)=0$. Kestabilan dari titik kesetimbangan sistem autonomous (berkaitan dengan vektor keadaan) nonlinear yang dilinierkan dapat ditentukan berdasarkan analisis kestabilan dari sistem autonomous linear seperti yang diberikan pada tabel 1 (Boyce dan DiPrima, 2009).
Tabel 1. Kriteria Kestabilan Titik Kesetimbangan Sistem Autonomous Nonlinear

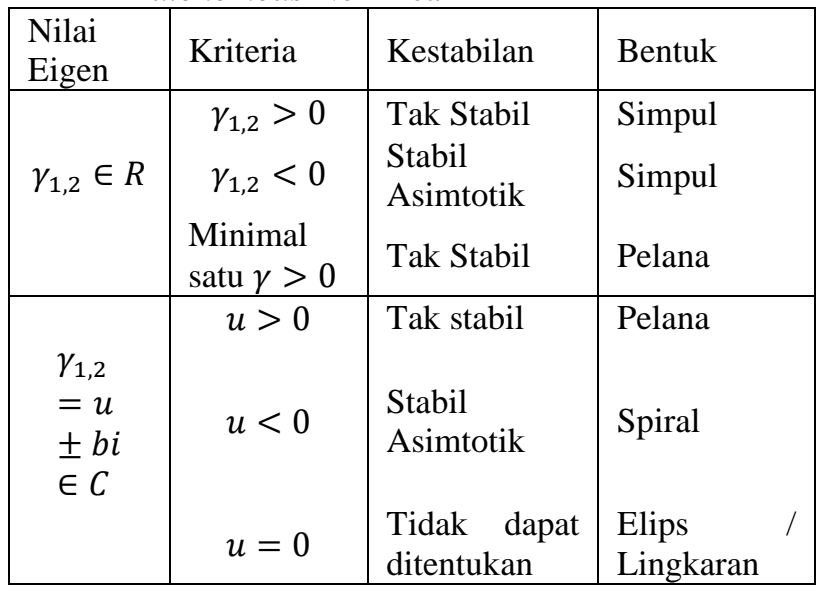

Pustaka [6] Diberikan sistem linear varian - waktu yang disajikan oleh persamaan (-4). Definisi keterkontrolan (controllability) adalah pada sistem linear persamaan (-4) dikatakan terkontrol bila untuk setiap keadaan sebarang $x(0)=x_{0}$ ada masukan $u(t)$ yang tidak dibatasi mentransfer keadaan $x_{0}$ ke sebarang keadaan akhir $x\left(t_{1}\right)=x_{1}$ dengan waktu akhir $t_{1}$ hingga. (Subiono, 2013) Teorema 1 : Syarat perlu dan cukup sistem persamaan (4) terkontrol adalah

1. Matriks $\omega\left(0, t_{1}\right)=\int_{0}^{t_{1}} e^{-A \tau} B B^{T} e^{A^{T}} d \tau$ non singular.

2. $M_{c}=\left(B|A B| A^{2} B|\ldots| A^{n-1} B\right)$ mempunyai rank sama dengan $n$.

Definisi keteramatan adalah jika setiap keadaan awal $x(0)=x_{0}$ secara tunggal dapat diamati dari setiap pengukuran keluaran sistem persamaan (-4) $t=0$ ke $t=$ $t_{1}$, maka sistem dikatakan 'teramati'.

Teorema 2 : Syarat perlu dan cukup sistem persamaan (4) teramati adalah

1. Matriks $m(0, t)=\int_{0}^{t} e^{-A^{T} \tau} C^{T} C e^{A^{T}} d \tau$ non singular.

2. $M_{0}=\left(C|C A| C A^{2}|\ldots| C A^{n-1}\right)^{T}$ mempunyai rank sama dengan $n$.

Pustaka [7] Model Schelling menguraikan bagaimana seorang individu menerima atau menolak uang suap secara rasional dengan mengasumsikan seorang individu memiliki pilihan biner $x \in[0,1]$ untuk menjadi koruptor $(x=1)$ atau tidak.

Pustaka [8] Model Lui menggunakan pendekatan generasi overlap untuk pembelajaran tingkah laku pegawai negeri yang memaksimalkan harapan membayar hukuman atau denda korupsi.

Pustaka [9] Model Blackburn et al menjelaskan bagaimana perkembangan ekonomi terhadap gangguan korupsi.

Pustaka [10] Model Mishra mempertimbangkan bagaimana korupsi dapat berkembang melalui sebuah teori evolusioner. 
Pustaka [11] Model Caulkins dkk membahas mengenai optimal kontrol nonlinear diterapkan pada kasus narkoba, korupsi, dan terror.

\section{HASIL DAN PEMBAHASAN}

A. Proses Linierisasi

Pada penelitian ini, linierisasi digunakan untuk melinierkan sistem kinerja lembaga Komisi Pemberantasan Korupsi dalam menangani kasus korupsi dengan sistem tersebut merupakan sistem persamaan nonlinier. Pendekatan linier dilakukan di sekitar titik kesetimbangan. Misalkan titik setimbang $\left(X_{1}^{*}, X_{2}^{*}\right)$, sehingga ekspansi deret Taylor adalah sebagai berikut. $\frac{d X_{1}}{d t}=f\left(X_{1}^{*}, X_{2}^{*}\right)+\left(X_{1}-X_{1}^{*}\right) \frac{\partial f}{\partial X_{1}}+\left(X_{2}-X_{2}^{*}\right) \frac{\partial f}{\partial X_{2}}+$ $\left(U-U^{*}\right) \frac{\partial f}{\partial U}+\cdots$

$\frac{d X_{2}}{d t}=g\left(X_{1}^{*}, X_{2}^{*}\right)+\left(X_{1}-X_{1}^{*}\right) \frac{\partial g}{\partial X_{1}}+\left(X_{2}-X_{2}^{*}\right) \frac{\partial g}{\partial X_{2}}+$ $\left(U-U^{*}\right) \frac{\partial g}{\partial U}+\cdots$

dengan

$f\left(X_{1}^{*}, X_{2}^{*}\right)=0$

$g\left(X_{1}^{*}, X_{2}^{*}\right)=0$

didefinisikan

$$
\begin{aligned}
& X_{1}-X_{1}^{*}=y_{1} \Rightarrow \dot{X}_{1}=\dot{y}_{1} \\
& X_{2}-X_{2}^{*}=y_{2} \Rightarrow \dot{X}_{2}=\dot{y}_{2} \\
& U-U^{*}=v_{1} \Rightarrow \dot{U}=\dot{v}_{1}
\end{aligned}
$$

Sehingga ekspansi deret taylor diatas menjadi

$$
\begin{aligned}
& \frac{d X_{1}}{d t}=y_{1} \frac{\partial f}{\partial X_{1}}+y_{2} \frac{\partial f}{\partial X_{2}}+v_{1} \frac{\partial f}{\partial U} \\
& \frac{d X_{2}}{d t}=y_{1} \frac{\partial g}{\partial X_{1}}+y_{2} \frac{\partial g}{\partial X_{2}}+v_{1} \frac{\partial g}{\partial U}
\end{aligned}
$$

Persamaan diatas dapat ditulis dalam bentuk matriks sebagai berikut.

$$
\left[\begin{array}{l}
\dot{y}_{1} \\
\dot{y}_{2}
\end{array}\right]=\left[\begin{array}{ll}
\frac{\partial f}{\partial X_{1}} & \frac{\partial f}{\partial X_{2}} \\
\frac{\partial g}{\partial X_{1}} & \frac{\partial g}{\partial X_{2}}
\end{array}\right]\left[\begin{array}{l}
y_{1} \\
y_{2}
\end{array}\right]+\left[\begin{array}{l}
\frac{\partial f}{\partial U} \\
\frac{\partial g}{\partial U}
\end{array}\right]\left[v_{1}\right]
$$

sehingga diperoleh hasil linierisasi sebagai berikut.

$$
\begin{aligned}
& {\left[\begin{array}{c}
\dot{y}_{1}(t) \\
\dot{y_{2}}(t)
\end{array}\right]=\left[\begin{array}{cc}
a-b X_{2} & -b X_{1} \\
b X_{2} & b X_{1}+c-d
\end{array}\right]\left[\begin{array}{l}
y_{1}(t) \\
y_{2}(t)
\end{array}\right]+} \\
& {\left[\begin{array}{c}
-e \\
0
\end{array}\right]\left[v_{1}(t)\right]}
\end{aligned}
$$

dengan matriks $Z$

$$
Z=\left[\begin{array}{cc}
a-b X_{2} & -b X_{1} \\
b X_{2} & b X_{1}+c-d
\end{array}\right]
$$

\section{B. Analisis Kestabilan}

Akar - akar persamaan karakteristik dari matriks Jacobi $Z$ adalah $\gamma_{1}$ dan $\gamma_{2}$. Nilai $\gamma_{1}$ dan $\gamma_{2}$ digunakan untuk menentukan jenis kestabilan titik kesetimbangan model sistem kinerja lembaga KPK dalam menangani kasus korupsi. Untuk memperoleh $\gamma_{1}$ dan $\gamma_{2}$ atau nilai eigen digunakan det $(\gamma I-Z)=0$ atau $\operatorname{det}(Z-\gamma I)=0$. Penyelesaian untuk menentukan nilai eigen dengan menggunakan det $(\gamma I-Z)=0$ sebagai berikut.

$$
\begin{aligned}
& \operatorname{det}\left[\left(\begin{array}{cc}
\gamma & 0 \\
0 & \gamma
\end{array}\right)-\left(\begin{array}{cc}
a-b X_{2} & -b X_{1} \\
b X_{2} & b X_{1}+c-d
\end{array}\right)\right]=0 \\
& \operatorname{det}\left[\left(\begin{array}{cc}
\gamma-a+b X_{2} & b X_{1} \\
-b X_{2} & \gamma-c-b X_{1}+d
\end{array}\right)\right]=0
\end{aligned}
$$

Pustaka [12] Model Richard dkk mengetahui tingkat korupsi di birokrasi dengan memperhatikan variabel state pegawai jujur dan pegawai yang korupsi.

$\left(\gamma-a+b X_{2}\right)\left(\gamma-c-b X_{1}+d\right)-\left(\left(-b X_{2}\right)\left(b X_{1}\right)\right)=0$

$\gamma^{2}-\gamma c-\gamma b X_{1}+\gamma d-a \gamma+a c+a b X_{1}-a d+$

$\gamma b X_{2}-b c X_{2}+b d X_{2}=0$

$\gamma^{2}+\left(-c-b X_{1}+d-a+b X_{2}\right) \gamma+a c+$

$a b X_{1}-a d-b c X_{2}+b d X_{2}=0$

Dari persamaan (-5) diperoleh akar - akar karakteristik sebagai berikut.

$$
\begin{aligned}
& \gamma_{1,2}=-\frac{\left(-c-b X_{1}+d-a+b X_{2}\right)}{2} \pm \\
& \frac{\sqrt{\left(-c-b X_{1}+d-a+b X_{2}\right)^{2}-4\left(a c+a b X_{1}-a d-b c X_{2}+b d X_{2}\right)}}{2}
\end{aligned}
$$

dengan

$$
\begin{aligned}
& \gamma_{1}=-\frac{\left(-c-b X_{1}+d-a+b X_{2}\right)}{2}+ \\
& \frac{\sqrt{\left(-c-b X_{1}+d-a+b X_{2}\right)^{2}-4\left(a c+a b X_{1}-a d-b c X_{2}+b d X_{2}\right)}}{2} \\
& \gamma_{2}=-\frac{\left(-c-b X_{1}+d-a+b X_{2}\right)}{2}- \\
& \frac{\sqrt{\left(-c-b X_{1}+d-a+b X_{2}\right)^{2}-4\left(a c+a b X_{1}-a d-b c X_{2}+b d X_{2}\right)}}{}
\end{aligned}
$$

Dari hasil yang diperoleh, jika $\gamma_{2}$ memenuhi kriteria kestabilan, maka $\gamma_{2}<0$ stabil asimtotik dengan syarat $c>d, X_{1}>X_{2}$ dan untuk $\gamma_{1}$ agar diperoleh stabil maka $\gamma_{1}<0$ dengan syarat sebagai berikut.

$\sqrt{\left(-c-b X_{1}+d-a+b X_{2}\right)^{2}-4\left(a c+a b X_{1}-a d-b c X_{2}+b d X_{2}\right)}<$ $\left(-c-b X_{1}+d-a+b X_{2}\right)$

$\left(-c-b X_{1}+d-a+b X_{2}\right)^{2}-4\left(a c+a b X_{1}-a d-\right.$ $\left.b c X_{2}+b d X_{2}\right)<\left(-c-b X_{1}+d-a+b X_{2}\right)^{2}$

$-4\left(a c+a b X_{1}-a d-b c X_{2}+b d X_{2}\right)<0$

$4\left(a c+a b X_{1}-a d-b c X_{2}+b d X_{2}\right)>0$

dengan syarat $\left(a c+a b X_{1}-a d-b c X_{2}+b d X_{2}\right)>0$ maka $\gamma_{1}$ stabil.

C. Analisis Keterkontrolan

Berdasarkan hasil proses linierisasi diperoleh matriks $Z$ dan $T$ sebagai berikut.

$$
\begin{aligned}
& Z=\left[\begin{array}{cc}
a-b X_{2} & -b X_{1} \\
b X_{2} & b X_{1}+c-d
\end{array}\right]_{\left(X_{1}^{o}, X_{2}^{o}\right)} \\
& T=\left[\begin{array}{c}
-e \\
0
\end{array}\right]_{\left(X_{1}^{o}, X_{2}^{o}\right)}
\end{aligned}
$$

dengan parameter yang diperoleh dari data laporan tahunan KPK 2017 - 2019, yaitu $a=0.353064, b=$ $0.161842, c=0.023524, d=0.156472, e=$

0.211696 , dan titik kesetimbangan yang memenuhi adalah $\left(X_{1}^{o}, X_{2}^{o}\right)=(5.2975,1.5010)$ sehingga diperoleh matriks $Z$ dan $T$ sebagai berikut.

$$
\begin{aligned}
& Z=\left[\begin{array}{cc}
a-b(1.5010) & -b(5.2975) \\
b(1.5010) & b(5.2975)+c-d
\end{array}\right]_{(5.2975,1.5010)}= \\
& {\left[\begin{array}{cc}
0.353064-0.161842(1.5010) & -0.161842(5.2975) \\
0.161842(1.5010) & 0.161842(5.2975)+0.023524-0.156472
\end{array}\right]_{(5.2975,1.5010)}} \\
& =\left[\begin{array}{cc}
0.11014 & 0.85736 \\
0.242925 & 0.72441
\end{array}\right]_{(5.2975,1.5010)} \\
& T=\left[\begin{array}{c}
-0.211696 \\
0
\end{array}\right]_{(5.2975,1.5010)}
\end{aligned}
$$

Berdasarkan teorema 1 bahwa syarat perlu dan cukup sistem terkontrol adalah $M_{c}=\left(T|Z T| Z^{2} T|\ldots| Z^{n-1} T\right)$ mempunyai rank sama dengan $n$. Sehingga diperoleh matriks $M_{C}$ sebagai berikut.

$$
M_{c}=\left[\begin{array}{cc}
-0.211696 & -0.0233 \\
0 & -0.0514
\end{array}\right]
$$


Karena matriks $M_{c}$ mempunyai rank sama dengan 2 maka sistem terkontrol.

D. Analisis Keteramatan

Berdasarkan hasil proses linierisasi diperoleh matriks $Z$ sebagai berikut.

$$
Z=\left[\begin{array}{cc}
a-b X_{2} & -b X_{1} \\
b X_{2} & b X_{1}+c-d
\end{array}\right]_{\left(X_{1}^{o}, X_{2}^{o}\right)}
$$

dan matriks $C=\left[\begin{array}{ll}1 & 0 \\ 0 & 1\end{array}\right]_{X_{1}^{o}, X_{2}^{o}}$ sebagai output dari persamaan (-2) dengan parameter yang diperoleh dari data laporan tahunan KPK 2017 - 2019, yaitu $a=0.353064$, $b=0.161842, c=0.023524, d=0.156472, e=$ 0.211696, dan titik kesetimbangan yang memenuhi adalah $\left(X_{1}^{o}, X_{2}^{o}\right)=(5.2975,1.5010)$ sehingga diperoleh matriks $Z$ sebagai berikut.

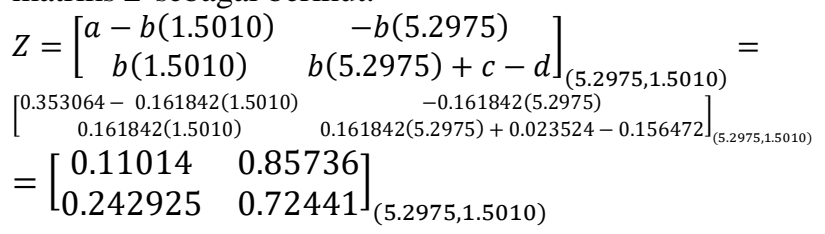

Berdasarkan teorema 2 bahwa syarat perlu dan cukup sistem teramati adalah $M_{o}=\left(C|C Z| C Z^{2}|\ldots| C Z^{n-1}\right)^{T}$ mempunyai rank sama dengan $n$. Sehingga diperoleh matriks $M_{o}$ sebagai berikut.

$$
M_{o}=\left[\begin{array}{cl}
1 & 0 \\
0 & 1 \\
0.11014 & 0.242925 \\
0.85736 & 0.72441
\end{array}\right]
$$

Karena matriks $M_{o}$ mempunyai rank sama dengan 2 maka sistem teramati.

\section{SIMPULAN}

Berdasarkan analisis dan pembahasan yang telah disajikan dapat disimpulkan bahwa dengan proses linierisasi menggunakan ekspansi deret Taylor diperoleh matriks Jacobi

$$
Z=\left[\begin{array}{cc}
a-b X_{2} & -b X_{1} \\
b X_{2} & b X_{1}+c-d
\end{array}\right]
$$

untuk menentukan analisis kestabilan, analisis keterkontrolan dan analisis keteramatan. Analisis kestabilan yang diperoleh adalah jika $\gamma_{2}$ memenuhi kriteria kestabilan, maka $\gamma_{2}<0$ stabil asimtotik dengan syarat $c>d, X_{1}>X_{2}$ dan untuk $\gamma_{1}$ agar diperoleh stabil maka $\gamma_{1}<0$. Analisis keterkontrolan yang diperoleh adalah $M_{c}=\left[\begin{array}{cc}-0.211696 & -0.0233 \\ 0 & -0.0514\end{array}\right]$ Karena matriks $M_{c}$ mempunyai rank sama dengan 2 maka sistem terkontrol. Analisis keteramatan yang diperoleh adalah $M_{o}=\left[\begin{array}{cl}1 & 0 \\ 0 & 1 \\ 0.11014 & 0.242925 \\ 0.85736 & 0.72441\end{array}\right]$ Karena matriks $M_{o}$ mempunyai rank sama dengan 2 maka sistem teramati.

\section{REFERENSI}

[1] Blackburn, K., Bose, N., Emranul Haque, M. (2006). The incidence and persistence of corruption economic development. Journal of Economic Dynamics and Control 39 (12). Hal. 2447-2467.
[2] Boyce, W. E., DiPrima, R. C. (2009). Elementary Differential Equations and Boundary Value Problems. 9th edition. John Willey and Sons Inc. United State of America.

[3] Bryson, A. E. dan Ho, Y. C. (1975). Applied Optimal Control. Halsted Press, New York.

[4] Grass, D., Caulkins, J.P., Feichtinger, G., dkk. (2008). Optimal Control of Nonlinear Processes: With Applications in Drugs, Corruption and Terror. Springer, Heidelberg.

[5] Naidu, D. S. (2002). Optimal Control Systems. CRC Press, New York.

[6] Subiono. (2013), Sistem Linier dan Kontrol Optimal, Jurusan Matematika, FMIPA ITS, Surabaya.

[7] Undang-Undang Republik Indonesia Nomor 31 Tahun 1999 tentang Pemberantasan Tindak Pidana Korupsi. 